\title{
MIĘDZY KULTURĄ A NATURAC̨. O PERSPEKTYWIE HISTORII ŻYCIA SŁÓW KILKA ${ }^{1}$
}

\author{
http://orcid.org/0000-0003-0680-7510
}

\section{Krzysztof Zamorski}

Uniwersytet Jagielloński w Krakowie

\section{ABSTRACT \\ BETWEEN CULTURE AND NATURE: SOME CONSIDERATIONS ON THE PERSPECTIVE OF LIFE HISTORY}

Life history is a term that in the historiography is usually assigned to the Italian school of microhistory. However, it is in fact a concept typical for the natural sciences, where it is a framework designed to examine life history strategies as well as life cycles. Analysis of life history has become the subject of numerous studies around the world and has been gaining in popularity in social sciences. The author presents life history as a possible research strategy for historical studies which allows the incorporation of both natural and cultural approaches. The author draws inspiration for the perspectives of life history research from the examples of recent research into the history of modern Poland.

Keywords: life history, microhistory, life course theory, quality analysis, biographical studies.

Słowa kluczowe: historia życia, mikrohistoria, teoria biegu życia, analiza jakościowa, biografistyka.

Sa ludzie, o których trudno jest powiedzieć coś takiego, co by od razu i całkowicie wyraziło ich najbardziej typowe i charakterystyczne cechy; to sa ci ludzie, których zazwyczaj nazywa się „, zwyktymi”, ,, większościa”” i którzy rzeczywiście stanowa większość każdego społeczeństwa. Pisarze w swych powieściach i romansach staraja się przeważie brać pewne typy społeczne i przedstawiać je obrazowo i artystycznie - typy nader rzadko spotykane w życiu jako pewne całości, a które jednak sa bardziej rzeczywiste niż sama rzeczywistość.

Fiodor Dostojewski, Idiota, cz. IV. R.I.

${ }^{1}$ Artykuł powstał w związku z realizacją projektu Fundacji Centrum Kopernika „Humanistyka w dialogu", finansowanego ze środków Ministerstwa Nauki i Szkolnictwa Wyższego w ramach programu „Dialog”; nr umowy 0239/DLG/2018/10. Jego angielska wersja ukaże się w specjalnym numerze „Historyki” (2021, t. 52, z. 2) przygotowanym z okazji XXIII Kongresu Nauk Historycznych w Poznaniu, w VIII $2022 \mathrm{r}$.

Adres do korespondencji: krzysztof.zamorski@uj.edu.pl 


\section{WPROWADZENIE}

W prezentowanym tu artykule chciałbym zająć się problemem perspektywy historii życia i podzielić się własnymi doświadczeniami z badań na tym polu. Poszukiwał będę zatem odpowiedzi na pytanie, jak można sobie wyobrazić perspektywę historii życia w badaniach historycznych oraz jakie konsekwencje wynikają z przyjęcia tej perspektywy dla narracji o dziejach. Podskórnie w swych najskrytszych marzeniach każdy z nas chciałby tak dotrzeć na płaszczyznę dziejów, aby niejako palpacyjnie dotknąć doświadczenia historycznego. Ideę tę najpełniej wyraził kiedyś nasz wybitny historyk Gerard Labuda, pisząc:

Historia szuka także człowieka, tylko mu nie stawia pytań w myśl oderwanych filozoficznych teorii, lecz chciałaby, aby on sam przemówił i powiedział wszystko, co wie o sobie; nie dość na tym - chciałaby ona wprowadzić go w to samo koło myśli i uczuć, w którym on niegdyś żył i działał, bo tylko w ten sposób dowiedzieć się można, jakie były pobudki jego czynów, należycie je zrozumieć i ocenić. Tymczasem my narzucamy nasze pojęcia ludziom innych czasów, zamiast zrozumieć ich własne, i to staje się często powodem nieporozumień, bo według pojęć dzisiejszych chcemy sądzić niedzisiejszych ludzi².

Zamiar ten zderza się jednak w praktyce z możliwościami i wymogami leżącymi w sferze naszego otoczenia kulturowego. Dosadnie oddaje to motto tych rozważań, w ciekawy sposób kierując nas ku problemowi, przed którym stoi historia życia. Chodzi bowiem nie tylko i nie tyle o kwestię, czy historycy postępują podobnie jak pisarze, bo na pewno tak się dzieje, ile o to, czy takie przedstawienie historyczne ma wartość i jaka to jest wartość. Czy takie postępowanie ma sens z punktu widzenia poznania czystego doświadczenia przeszłości, o którym pisze Labuda w przytoczonych powyżej słowach?

Pytając o istotę perspektywy historii życia, należy sięgnąć do filozoficznych, społecznych i historycznych uwarunkowań spojrzenia na świat, w którym interesuje nas specyficzny „sposób traktowania człowieka, zmierzający do wydobycia i uchwycenia jego najważniejszych spraw"3. Chciałbym zatem, aby perspektywa historii życia zakładała przede wszystkim, że jej punktem fokusowym jest konkretny człowiek i konkretne życie z przeszłości, a najważniejsze wydarzenia dzieją się w życiu człowieka od jego narodzin do śmierci. Tak wyznaczona przestrzeń życia stanowi pierwsze i najważniejsze granice chronologiczne rozważań. Należy przy tym uznać, że jakkolwiek często uczestniczy on w wydarzeniach ważnych, czy też jedynie za takie uznanych społecznie, to interesuje nas jego - ludzkiego indywiduum - ogląd tych wydarzeń i jego ocena ich wagi oraz znaczenia. Nie zawsze jednak jest to możliwe i trudno z tej perspektywy wykluczyć ujęcia, w których przedmiotem analizy stają się składniki historii życia człowieka: niemowlęctwo, dzieciństwo, młodość, wiek

${ }^{2}$ G. Labuda, Święty Wojciech w polskiej tradycji historiograficznej, Warszawa 1997, s. 36. Cytat ten zawdzięczam niewydanej jeszcze książce Andrzeja Kobaka o Karolu Potkańskim. Praca niebawem ukaże się w Wydawnictwie Uniwersytetu Łódzkiego. Korzystam z niego za zgodą autora.

3 J. Kuczyński, Filozofia życia, Warszawa 1965, s. 97. 
dojrzały czy starość. Podobnie trudno wykluczyć te elementy, w których edukacja, wyznawane idee, służba wojskowa czy traumatyczne przeżycia okresu wojny determinują ludzkie spojrzenie na bycie w czasie. Wszystkie one - jak wiemy - mają swą potężną literaturę w historiografii powszechnej i naszej rodzimej, której nie sposób zanegować czy odrzucić. W perspektywie historii życia chodzi jednak o sprawy najważniejsze z punktu widzenia konkretnego ludzkiego istnienia, nie zaś przede wszystkim o życie człowieka w perspektywie najważniejszych wydarzeń i spraw grupy społecznej bądź instytucji takich jak kościoły, związki wyznaniowe czy państwo. Bowiem państwo, religia, partie polityczne, działania gospodarcze nie stają się „bardziej rzeczywiste niż rzeczywistość”, jak mówił Dostojewski, tylko wówczas jeśli popatrzymy na nie z perspektywy życia konkretnego człowieka.

Podejmuję to zagadnienie, bo w wielu krajach, łącznie z moim rodzinnym: Polską, w narracji historycznej nadal dominuje perspektywa wykluczająca historię życia jako punkt fokusowy, co pozostaje w sprzeczności z tym, co czeka nas w epoce antropocenu i problemów, jakie niesie współczesny świat oraz jego przyszłość. Przeważa perspektywa o instytucjonalnym punkcie fokusowym, w którym zasadniczą rolę odgrywa nie człowiek, a naród, partia polityczna, religia czy grupa społeczna. Życie ludzkie jest tu jedynie elementem składowym tej całości. Stanowi swoisty dodatek, a nie esencję zjawisk społecznych. Przyjęta typologia grup społecznych i otaczających nas zjawisk staje się ważniejsza aniżeli indywidualne doświadczenie życia, w oparciu o które te typologie są możliwe.

Jednocześnie stosując tę perspektywę, stosujemy ją my - historycy żyjący i tworzący, prezentujący określoną kulturę poznającą, jak słusznie zauważa Jan Pomorski. Mówiąc o kulturze poznającej, badacz ma na myśli

rodzaj autorefleksji kultury poznającej, która przemyśliwując samą siebie, odkrywa/uświadamia sobie swoją nie ponadczasowość, ale historyczność (zmienność właśnie) i tym doświadczeniem różnych form obecności (i nieobecności) przeszłości w teraźniejszości stara się podzielić ze społeczeństwem ${ }^{4}$.

Najogólniej rzecz biorąc, koncept ten decyduje, że to my wybieramy punkt fokusowy. Jego, czyli tego punktu, zachowania i opinie postrzegamy w naszych kategoriach kultury poznającej historyka, która jest kulturą innej czasoprzestrzeni, a w tym i specyficzną kulturą poznania przeszłości, opartą na wzorcach postrzegania przeszłości dostępnych i akceptowalnych w naszej kulturze. Akceptowalne oznacza, że nie zawsze są to wzorce jedynie akceptowane, ale często obce naszej kulturze.

Patrzymy na kulturę poznawaną, która determinuje zachowania i opinie punktu fokusowego. Zazwyczaj mamy do czynienia z sytuacją, w której te zachowania nie są prostym potwierdzeniem cech tamtej kultury, a nawet mogą pozostawać z nią w sprzeczności. Element spojrzenia w przeszłość, który w przypadku perspektywy historii życia jest problemem fundamentalnym, to założenie o różnicach czasoprzestrzeni punktu obserwacji i czasoprzestrzeni punktu obserwowanego. Istotny element tego zabiegu stanowi konieczność uświadomienia sobie tej odmienności

${ }^{4}$ J. Pomorski, Homo Metahistoricus. Studium sześciu kultur poznających historię, Lublin 2019, s. 3. 
i konieczności intencjonalnego wejścia na płaszczyznę dziejów jako płaszczyznę obserwowaną, co definiuje kwestię ontologii historii ${ }^{5}$.

\section{KILKA UWAG O FILOZOFICZNYCH KORZENIACH KONCEPCJI}

Pytanie o rolę kultury poznającej kieruje naszą uwagę ku filozofii życia jako ideowej podstawie spojrzenia na dzieje. Życie jako kategoria myślenia filozoficznego ma za sobą wielką przeszłość. Jak pisze Herbert Schnädelbach, w Niemczech stanowiło kiedyś, a dokładnie w latach 1880-1930, temat filozoficzny, który zdominował wszystkie inne pojęcia, takie jak „byt”, „przyroda”, „Bóg” czy ,ja”.

Fundamentalny przy tym jest fakt, że wywodzi się ona w istocie z niemieckiej filozofii życia Lebensphilosophie (Philosophie des Lebens) i wiąże się z rozwiniętą fazą historyzmu - praktyki badawczej historii wykształconej w pierwszej połowie XIX wieku, szczególnie zaś z myślą Wilhelma Diltheya. Historyk staje w niej potencjalnie na pozycji filozofa. Jak pisze niezapomniana Elżbieta Paczkowska-Łagowska:

Dilthey poczytywał sobie za zasługę, że w odróżnieniu od całej dotychczasowej filozofii dopiero w stworzonej przez siebie filozofii życia określanej w języku niemieckim mianem geschichtliche Lebensphilosophie, filozofii uwzględniającej dziejowy wymiar życia, doszło do głosu pełne i zniekształcone doświadczenie, co pozwoliło mu na zrównanie filozofii życia i filozofii rzeczywistości. Po upadku systemu Heglowskiego życie pojawia się u Diltheya jako jedyny rodzaj „absolutu”, do którego ujęcia może jeszcze pretendować filozofia, która nie chce już być więcej spekulacją, lecz analizą doświadczenia. W ramach krytyki rozumu historycznego tą całością jest życie ludzkie, już zawsze osadzone w dziejach i dostępne na drodze poznawczej przesz swoje uzewnętrznienia (uprzedmiotowienia), ,wytwory ludzkiego ducha”, które mogą być zrozumiałe dlatego, że duch ludzki je wytworzył?

Intencjonalnie Dilthey miał na myśli przede wszystkim jednostki sprawcze, kreujące i oddziałujące na bieg dziejów. W perspektywie bliskiej naszej kulturze poznającej nie jest to już jedyny i ważny wyznacznik zainteresowania przeszłością. Wraz z rozwojem antropologii interesują nas wszystkie przejawy życia człowieka w przeszłości zapisane w śladach jego kultury. W ten sposób możemy dzisiaj odczytywać intencje Diltheya, kiedy zwraca uwagę, że koncentracja naszego poznania na konkretnym życiu nie prowadzi nas do poznania wyłącznie tego konkretnego życia. Dzieje się tak, bowiem wedle Diltheya ,jednostka stanowi punkt przecięcia

${ }^{5} \mathrm{O}$ tej potrzebie, jej ograniczeniach i możliwościach szerzej piszę w: K. Zamorski, Dziwna rzeczywistość. Wprowadzenie do ontologii historii, Kraków 2008, rozdziały IX i X. Zob. też: idem, Zagadnienie przestrzeni ontologicznej w historii [w:] Gra i konieczność. Zbiór rozpraw z filozofii historii i historii historiografii, red. G. Dominiak, J. Ostoja-Zagórski, W. Wrzosek, Bydgoszcz 2005, s. $17-34$.

${ }^{6}$ H. Schnädelbach, Filozofia w Niemczech 1831-1933, thum. K. Krzemieniowa, Warszawa 1992, s. 216.

${ }^{7}$ E. Paczkowska-Łagowska, Logos życia. Filozofia hermeneutyczna $w$ kręgu Wilhelma Diltheya, Gdańsk 2000, s. 32-33. 
różnych systemów [...] wzajemnych oddziaływań" " [podkreśl. - K.Z.]. W tym sensie docieramy do różnych - jak pisze Paczkowska-Łagowska - „odniesień, relacji i zależności”. Historyk zatem jako kultura poznająca dociera do śladów kultury poznawanej, czyli wkracza na płaszczyznę dziejów. Wejście na płaszczyznę dziejów wiąże się z konieczną imputacją kulturową, którą niesie z sobą świadomość historyczna kultury poznającej. Sam Dilthey będzie o niej mówil, że świadomość historyczna niesie z sobą siłę niszczącą wobec różnorodności i złożoności świata poznawanej kultury ${ }^{9}$ W jakimś sensie rzeczywiście docierając na płaszczyznę dziejów, przypisujemy jej cechy naszej kultury. Chodzi jednak o to, by w oparciu o studium konkretnego doświadczenia życia te imputacje weryfikować ku pożytkowi naszego pojmowania świata. Jak, moim zdaniem słusznie, zauważył Andrzej Przyłębski,

Dilthey stwierdził, że istota ludzka żyje jakby w trzech głównych wymiarach egzystencjalnych: emocjonalnym (uczuciowym), wolicjonalnym (działaniowym) i poznawczym (intelektualnym), które wzajemnie do siebie odniesione stanowią całość podlegającą jedynie umownej, filozoficznej analizie ${ }^{10}$.

Równocześnie jednak zarówno Przyłębski, jak i inni badacze podkreślają, że kategoria życia dla Diltheya, jakkolwiek formalnie nie jest całkowicie ograniczona do człowieka, to jednak widzi życie przede wszystkim jako kategorię ludzką. Inna rzecz, że dostrzega coś, co w konsekwencji prowadzi do przełamania bariery wyłącznie kulturowego spojrzenia na życie ludzkie:

W odróżnieniu od nich [Husserla i Heideggera - przyp. K.Z.] Dilthey, podkreślając napięcie między wewnętrznością życia oraz istnieniem obiektywizacji kulturowych, uwzględniał dywergencję zachodzącą między dwoma niewspółmiernymi przejawami życia: tym, co - jak powiedziałby Hegel - mieści się w sferze ducha subiektywnego (tzn. tego, co psychiczne, czysto świadomościowe), i tym, co przynależy sferze ducha obiektywnego (tzn. intersubiektywnie dostępnym dziełom i instytucjom, zmaterializowanym przejawom życia). Jak słusznie podkreśla G. Arlt, życie to dla Diltheya coś więcej niż sposób samorealizacji świadomości duchowo-kulturowe postaci życia mają swą podstawę w życiu biologicznym, „im naturgebundenem Leben” [podkreśl. - K.Z.]. Sprawcą przemian historyczno-kulturowych jest „,cały człowiek", w swej psychofizycznej jedności ${ }^{11}$.

Cytowany już Schnädelbach w całym nurcie niemieckiej filozofii życia wyróżnia jej trzy rodzaje: metafizyczną, historiozoficzną i etyczną ${ }^{12}$. Najbardziej nas tu

${ }^{8}$ W. Dilthey, Gesammelte Schriften, B.G. Teubner Verlagsgeselschaft, Stuttgart, Vandenhaeck co. Ruprecht in Göttingen, vol. 5, s. 63, cyt. za: E. Paczkowska- Łagowska, op. cit., s. 109.

9 „Dążeniem człowieka dzisiejszego jest zrozumieć życie przeżywane przez człowieka. Różnorodność systemów, które zmierzały do objęcia struktury świata, pozostaje w jawnym związku z życiem; jest ona jednym z najważniejszych i najbardziej pouczających jego wytworów i w ten sposób samo wykształcenie się świadomości historycznej, która dokonała tak niszczącego dzieła wobec wielkich systemów, będzie musiało być nam pomocne w zniesieniu ostrej sprzeczności pomiędzy pretendowaniem systemów filozoficznych do ważności powszechnej a historyczną anarchią [panującą wśród] tych systemów", W. Dilthey, O istocie filozofii i inne pisma, Warszawa 1987, s. 119.

${ }^{10}$ A. Przyłębski, Hermeneutyczna antropologia Wilhelma Diltheya, „Analiza i Egzystencja” 2010, nr 19, s. 70.

${ }^{11}$ Ibidem, s. 39.

${ }^{12}$ H. Schnädelbach, op. cit., s. 231. 
interesujący nurt historiozoficzny zakłada, że trudno przyjąć, aby kultura poznająca przeszłość abstrahowała od fizycznej strony bycia człowieka, innymi słowy, od ujęć, które dzisiaj, często powierzchownie, określamy mianem naturalistycznych. W praktyce prowadzi to często narrację historyka w kierunku biospołecznych uwarunkowań ludzkiego życia, a samo pojmowanie przeszłości może być widziane zarówno $\mathrm{w}$ aspekcie kultury, jak i w aspekcie natury.

Taka interpretacja życia otwiera nas niewątpliwie na nowe możliwości, ale też niesie z sobą zagrożenia. Oswalda Spenglera na przykład prowadziła do stworzenia naturalistycznej, pesymistycznej w istocie teorii dziejów, opartej na wzajemnej relacji dwóch zasadniczych odmian życia: Dasein (bytu, który Spengler pojmował jako istnienie bezwiedne, wegetatywne, roślinne) oraz Wachsein (istnienia rozbudzonego, świadomego i samoświadomego, nacechowanego wewnętrznym napięciem, swobodnego). Dla niego życie organiczne było

zjawiskiem pierwotnym, ideą urzeczywistniającą się z możliwości, na wskroś tajemniczym procesem przebiegającym przed naszymi oczyma. Idea życia wszędzie ma podobną formę wewnętrzną: płodzenie, narodziny, rośnięcie, zanik - identyczną od najmniejszego wymoczka aż po potężną kulturę ${ }^{13}$.

Życie organiczne było dla Spenglera głęboką jednością powstałą i przemijającą, mającą swój koniec i początek, przechodzącą naturalny cykl: od narodzin, przez rozwój, wiek dojrzały po śmierć. Wszelkie powstające twory powtarzają ten wielki proces - od potężnych grup ludzkich aż po życie jednostkowe, co najsilniej wyraża się w człowieku kultury. Obie wspomniane wyżej formy bytu pojawiają się w myśli Spenglera w różnych miejscach i do pełnej interpretacji należy brać pod uwagę całość jego określeń. Andrzej Kołakowski, znawca myśli Spenglera, powiada, że

na podstawie tych i wielu podobnych sformułowań można powiedzieć, że istnienie pierwotne [Dasein - przyp. K.Z.] jest wewnętrznie jednolite, charakteryzuje je takt, pęd, kierunek czy też los, przeznaczenie, brak mu natomiast elementu samoświadomości. Istnienie złożone [Wachsein - przyp. K.Z.] wiąże się z napięciem, biegunowością, rozciągłością — jest pojęciem dwoistym, składają się nań człony opozycyjne napięciowe i jest ono wyposażone w nadbudowę świadomości ${ }^{14}$.

Koncepcję Spenglerowskiej historiozofii historii życia można traktować jako myśl sięgającą do idei Lebensphilosophie Diltheya, ale tak naprawdę ją zniekształcającą i wobec niej epigońską ${ }^{15}$. Smutna i drapieżna wizja historii życia w koncepcji

${ }_{13}$ O. Spengler, Urfragen. Fragemente aus dem Nachlass, München 1962, s. 1. Przekład polski: A. Kołakowski, Spengler, Warszawa 1981, s. 1; zob. też: O. Spengler, Historia, kultura, polityka. Wybór pism, tłum. A. Kołakowski, J. Łoziński, Warszawa 1990, s. 9.

${ }^{14}$ A. Kołakowski, Życie-kultura-cywilizacja. Historiozofia Oswalda Spenglera jako wyraz kryzysu i krytyki kultury, „Archiwum historii filozofii i myśli społecznej” 1976, T. 22, s. 108.

${ }^{15}$ Tak widzi ją na przykład znawca filozofii Spenglera, Andrzej Kołakowski, pisząc: „Widać zatem u Spenglera - co prawda w karykaturalnej formie - elementy takiego badania, które od Diltheya prowadziło do współczesnej humanistyki rozumiejącej i jej strukturalizującego aspektu, ale zarazem uderza pozytywistyczny naturalizm i to mocno zwulgaryzowany. W dziele tego epigona Lebensphilosophie ujawnia się więc wyraziście to, co było zawarte w samej tej filozofii, lecz przesłaniane potęgą wysiłku intelektualnego jej czołowych przedstawicieli i dramatyzmem poszukiwań”, ibidem, s. 107. 
Spenglera nie jest zatem jedyną, jaką można wywieść ze źródeł filozofii życia. Herbert Schnädelbach jako przykład takiego podejścia przywołuje filozofię kultury Zygmunta Freuda wyrażaną w jego późnych pismach ${ }^{16}$. Filozofia życia, odgrywająca tak aktywną rolę w początkach poprzedniego stulecia, uległa swoistemu zapomnieniu. Została wchłonięta przez filozofię egzystencji i egzystencjalizm ${ }^{17}$. W jakimś sensie jej kontynuacją jest dzisiaj antropologia filozoficzna ugruntowana w myśli Maxa Schelera, Helmutha Plessnera czy Arnolda Gehlena. Trudno nie zauważyć związków myśli Diltheya z rozwojem niemieckiej filozofii hermeneutycznej. Badacze zagadnienia zwracają jednak uwagę, że na przykład Heidegger, podobnie jak Husserl, nie był w stanie skorzystać z propozycji Diltheya prowadzących w kierunku zarówno biologicznej, jak i kulturowej analizy ludzkiej egzystencji. Husserl, jak to wykazuje w swej ciekawej analizie William Casement, podziwiając pewność nauk przyrodniczych, nie uznaje, że można wszystko widzieć w kategoriach przyrodniczych; sądził, że konieczne jest podejście wykraczające poza fizyczność zjawisk ${ }^{18}$. Co więcej, historycy podobnie jak przedstawiciele nauk przyrodniczych

nie wnikają w prawdziwą rzeczywistość. Jest do tego zdolny tylko filozof, posługując się metodą fenomenologiczną Husserla. Ujmując to inaczej, filozof zajmuje się prawdą o istocie, podczas gdy przyrodnicy i humaniści, niezależnie od tego, czy koncentrują się na fizyczności (zdarzenia), czy psychice (idee), zajmują się faktami, które z konieczności podlegają relatywizmowi, bo rodzą się na gruncie postawy naturalistycznej ${ }^{19}$.

Husserl zatem wedle tego autora dostrzega różnicę między ujęciami ogólnymi i rozumiejącymi właściwymi filozofii oraz praktyką poznania szczegółowego właściwego naukom przyrodniczym i humanistycznym. Herbert Schnädelbach zauważa również związek filozofii życia z koncepcjami neomarksizmu. Pisze:

Nawet neomarksizm od czasu Lukácsa i frankfurcka teoria krytyczna przenoszą jej obiegowe kulturowo-krytyczne toposy, chociaż wciąż usiłują wyraźnie odgraniczać się od ,irracjonalistycznej" filozofii życia. Metafizyczne zaangażowanie po stronie tego, co dynamiczne, przeciwko temu, co statyczne, za którym niezbyt skutecznie ukrywa się przeciwstawienie martwego i żywotnego, stapia się tutaj z recepcją marksistowskiej krytyki fetyszyzmu towarowego, dzięki której „,urzeczowienie” staje się podstawowym pojęciem kultury"20.

Prowadzi nas to w kierunku dobrze znanej w historii historiografii ubiegłego stulecia włoskiej koncepcji „historii życia”. Giovanni Levi, Carlo Poni i Carlo Ginzburg, włoscy ojcowie mikrohistorii, nie odżegnując się od marksizmu, wychodzą z nieco

${ }^{16}$ H. Schnädelbach, op. cit., s. 241 .

17 Ibidem.

18 W. Cas ement, Husserl and the philosophy of history, „Theory and History” 1988, vol. 27, no. 3, s. 231 .

19 "While historians focus on ideas and not simply on physical events, they do not penetrate true reality. It is only the philosopher who, using Husserl's phenomenological method, is capable of this. To put it another way, the philosopher deals with the truth of essence, while natural and humanistic scientists, whether they concentrate on the physical (events) or the psychical (ideas), deal with facts which are necessarily subject to relativism since they are conceived from within the prejudices of the natural attitude". W. Casement, op. cit., s. 231.

${ }^{20}$ H. Schnädelbach, op. cit., s. 17. 
innych założeń. Chcą tę historię widzieć po stronie antropologii kulturowej, stąd jej otwartość również na koncepcje antropologii filozoficznejej ${ }^{21}$ Jeśli idzie o inspiracje filozoficzne, chodzi im bardziej o społeczne uwarunkowania życia człowieka, które on sam nie zawsze sobie uświadamia. Sięgają więc do słów jednego z ojców współczesnej antropologii kulturowej, Claude’a Lévi-Straussa, a dokładniej do jego Wprowadzenia do antropologii strukturalnej, w którym znalazły się słynne słowa Marksa: „Ludzie sami tworzą swoją historię, ale nie tworzą jej dowolnie, nie w wybranych przez siebie okolicznościach, lecz w takich, w jakich się bezpośrednio znaleźli, jakie zostały im dane i przekazane"22. Taką historię Ginzburg i Poni chcą nazwać „nauką realnego życia” (science of real life) - historią życia. Historią, w której wielość ludzkich doświadczeń każe zastanowić się nad granicami uogólnień historycznych proponowanych zarówno w historyzmie, jak i modernizmie (,Annales"). Jak to pięknie ujmują:

We propose therefore to define microhistory and history in general as the science of real life [science del vissuto], definition that seeks to comprehend the reasoning of both the supporters and the enemies of history with the social sciences, and for this, no doubt, it will be pleasing to either side ${ }^{23}$.

\section{HISTORIA ŻYCIA I HISTORIA}

Pojęcie „historii życia” funkcjonuje w naukach społecznych, w socjologii, demografii czy nawet w ekonomii. Nie jest tam traktowane do końca jednakowo i jednoznacznie. Różni się od pojęcia life history przyjmowanego w naukach przyrodniczych, szczególnie w ewolucjonizmie, co nie znaczy, że i tutaj nie można znaleźć punktów stycznych ${ }^{24}$. Osobiście jednak jestem przekonany o szczególnej wartości, jaką dla historii życia w historii stanowi mikrohistoria; musi ona być jednak widziana i stosowana w relacji do badań szerokiego zasięgu, tak jak kiedyś postulował

${ }^{21}$ C. Ginzburg, C. Poni, The Name and the Game. Unequal Exchange and Historiographic Marketplace, Microhistory and the Lost People of Europe, eds. E. Muir, G. Ruggiero, Baltimore 1991, s. 4. Szerzej o tej koncepcji zob. C. Ginzburg, Microhistory: Two or Three Things That I Know About It, „Critical Inquiry” 1993, vol. 20, no. 1, thum. J. Tedesch i, A.C. Tedeschi, s. 10-35.

22 "Die Menschen machen ihre eigene Geschichte, aber sie machen sie nicht aus freien Stücken, nicht unter selbstgewählten, sondern unter unmittelbar vorgefundenen, gegebenen und überlieferten Umständen. Die Tradition aller toten Geschlechter lastet wie ein Alp auf dem Gehirne der Lebenden", K. Marx, Der achtzehnte Brumaire des Louis Bonaparte [w:] K. Marx, F. Enge1s, Werke, Band 8, Dietz Verlag, Berlin/DDR 1972, s. 115.

${ }^{23}$ „Dlatego proponujemy określić mikrohistorię i historię w ogóle jako naukę o prawdziwym życiu [science del vissuto] definicją, która dąży do zrozumienia rozumowania zarówno zwolenników, jak i przeciwników historii w naukach społecznych i z tej racji niewątpliwie zadowoli obie strony", C. Ginzburg, C. Poni, op. cit., s. 8-9.

${ }^{24} \mathrm{~K}$. Zamorski, Historia życia u źródet. Włoski korzenie [w:] Badacze przeszłości wobec wyzwań XIX-XXI wieku, red. K. Błachowska, Z. Romek, M. Wolniewicz, Warszawa 2013, s. 285-292. 
Giovanni Levi. Historia życia w historii nie może być omówiona bez sięgnięcia do osiągnięć i założeń mikrohistorii.

Mikrohistoria bowiem odegrała istotną rolę we współczesnej historiografii jako idea nowego spojrzenia na historię w ostatnich dziesięcioleciach ubiegłego wieku. Dla polskiej historiografii tak ją odkrywa i przedstawia w swej ciągle aktualnej i bardzo wartościowej pracy Ewa Domańska. Patrzy na mikrohistorię niekoniecznie taką, jak widział ją Levi, ale w wersji już zmodyfikowanej przez autorów takich klasycznych prac z tego zakresu, jak Carlo Ginzburg (z czasu, gdy napisał Ser i robaki), Robert Darnton, Natalie Zemon Davis czy Emmanuel Le Roy Ladurie ${ }^{25}$.

Giovanni Levi, który jako pierwszy spróbował przeciwstawić Braudelowskiej makrohistorii swój koncept nowej historii społecznej, opiera się właśnie na mikrohistorii. Widzi tę ostatnią jako historię na swój sposób uniwersalną (gospodarczą, społeczną, kultury), ale bazującą na badaniach prowadzonych w „zredukowanej skali obserwacji”. To właśnie zredukowana skala poprzez studia wielu przypadków indywidulanych zdarzeń i zjawisk uwikłanych w sieć społecznych powiązań powinna dostarczyć danych pozwalających weryfikować sądy wynikające $\mathrm{z}$ analiz makrostrukturalnych. Levi nie neguje więc wartości ujęć makroanalitycznych, wręcz zwraca uwagę, że oparcie historii wyłącznie o mikroanalizę może prowadzić do powrotu do historii targanej nacjonalistycznymi i ksenofobicznymi wizjami dziejów. Konieczne jest zatem postrzeganie zalet zredukowanej skali obserwacji w relacji do ograniczeń obserwacji makro. Podejmuje też polemikę z konceptem gęstej analizy tekstu Clifforda Geertza, obawiając się, że w przypadku mikrohistorii może ona prowadzić do mikroprozopografii ${ }^{26}$.

Z kolei Poni i Ginzburg pisali przywoływany wyżej artykuł w momencie wielkiej dominacji konceptualnej szkoły Annales. Zdawali sobie rzecz jasna sprawę z wielości idei i podejść metodologicznych annalistów. Odnosili się jednak przede wszystkim do dominującego wówczas konceptu historii serii lansowanego przez Pierre'a Chaunu. Osobiście dopatruję się w koncepcie historii serii próby odpowiedzi środowiska Annales na szybko wówczas postępujący proces kwantyfikacji badań historycznych, szczególnie zaś na nośne interpretacyjnie badania new economic history ${ }^{27}$. Szkoła Annales miała za sobą szereg mocnych argumentów w kwantyfikacji historii, od historii klimatu i badań kwantytatywnych Le Roy Laduriego nad wsią langwedocką, przez studia Chaunu nad Sewillą i Atlantykiem, po fantastyczne osiągnięcia francuskiej demografii historycznej i wypracowaną metodę rekonstrukcji rodzin Henriego. Tak bliska Braudelowi idea pracy grupowej, grup badawczych zbliżała historię kwantytatywną do wzorca nauk przyrodniczych. Badania masowe określały i wyraźnie

${ }^{25}$ E. Domańska, Mikrohistorie. Spotkania w międzyświatach, Poznań 1999. Por. szczególnie część III.

${ }^{26}$ K. Górzan, Giovanniego Leviego koncepcja mikrohistorii, „Historyka. Studia Metodologiczne" 2007-2008, T. 37-38, s. 77-90. Zob. też E. Domańska, Mikrohistorie, Poznań 1999 (wyd. drugie 2005), s. 58.

${ }^{27} \mathrm{O}$ koncepcie historii serii w momencie jego narodzin miałem okazję wówczas pisać. Por. K. Zamorski, Czym jest historia serii Pierre Chaunu?, „Zeszyty Naukowe UJ. Prace Historyczne” 1980, z. 66, s. 139-150. 
preferowały jeden rodzaj źródeł - źródła o charakterze masowym - pozostawiając na boku wiele innych bogatych, ale o odmiennym charakterze. Braudelowskie podejście długiego trwania doskonale odpowiadało strukturalizmowi i w założeniu miało odkrywać struktury. Obaj włoscy uczeni nie negowali więc wartości uchwycenia mechanizmów kierujących kryzysami maltuzjańskimi. Co więcej, twierdzili, że uczyniło to historię nauką według terminologii Kuhna, kształtując jej paradygmat. Stwierdzili jednak, że podejście długiego trwania przy wszystkich swoich zaletach spycha na margines żywe ludzkie doświadczenia: „Lived experience (undoubtedly an ambigious expression) is largely relegated to the margins" 28 .

Nadzieją napawały ich te nurty badań, które wyrosły niejako obok ówczesnego makrostrukturalnego mainstreamu. Zwrócili bowiem uwagę na rolę badań regionalnych, monografii małych miejscowości, analiz docierających do historii poszczególnych rodzin czy indywidualnych ludzkich doświadczeń. Mieli zresztą już wówczas doskonałe punkty odniesienia na gruncie włoskim. Stanowiły je zarówno idee propagowane przez czasopismo „Quaderni Storici”, jak i w szczególności wspomniana wyżej twórczość Giovanniego Leviego. Rozwój perspektywy mikrohistorycznej i jej sukcesy zderzały się w ich przekonaniu z narastającymi wątpliwościami co do ustaleń makrohistorycznych, wykazując ich małą przydatność w ukazaniu szeregu aspektów ludzkiego życia. Mikrohistoria w ostatnich dziesięcioleciach zespoliła się konceptualnie z historią kultury. Dla wielu stała się niemalże sztandarowym przykładem zwrotu kulturowego w historiografii.

W tym spojrzeniu brakuje mi jednak tego, co w praktycznych badaniach leżało kiedyś u podstaw kulturowych interpretacji przeszłości i antropologizacji historii wyrażonej choćby w pracach Filipa Arièsa - bardziej właśnie jego niż innych przedstawicieli tzw. trzeciej generacji szkoły Annales. Mam na myśli skuteczność rozwiniętej we francuskiej, a potem światowej demografii historycznej metody rekonstrukcji rodzin. Metoda ta, zwana nominalną analizą rejestrów parafialnych, jest w istocie esencją mikrohistorii w tym sensie, w jakim sieć powiązań jest budowana w oparciu o analizę poszczególnych rodzin, swoistą mikrohistorię. Szereg kwestii, jak na przykład zachowanie populacji tradycyjnych w okresach kryzysów subzystencjalnych czy zmian płodności, postawy badanych populacji wobec śmierci, narodziło się w tym obszarze. Szczegółowa analiza prowadziła do wniosków ogólnych o szerokim, klasycznie makrostrukturalnym zasięgu. Tak się stało na przykład w badaniach Cambridge Group for Population Studies, które przyniosły koncept modeli Rogera Schofielda próbujących wyjaśnić drogi zmian biospołecznych prowadzących do narodzin kapitalizmu w Anglii.

Dlatego stoję na stanowisku, że efektem tego rozwoju w przyszłości będzie swoista fuzja tego, co dzisiaj nazywamy i rozumiemy pod nazwą ,,antropologii historycznej” oraz niektórych idei epoki HSS. Chciałbym widzieć efekt tej fuzji w koncepcie, który dla potrzeby własnej nazywam - może i trochę niezdarnie - „historią życia”. Ewa Domańska w jakimś sensie myśli podobnie, określając ten rodzaj historii mianem „historii egzystencjalnej”. Wychodząc od pojęcia wprowadzonego do analiz

\footnotetext{
${ }^{28}$ C. Ginzburg, C. Poni, op. cit., s. 3.
} 
historiograficznych przez Jerzego Maternickiego, odróżnia ją od historii egzystencjalistycznej i tak opisuje jej zadania:

Jest to raczej perspektywa badawcza, która w dociekaniach na temat historii oraz teorii i historii historiografii, prowadzonych przez pryzmat autorów i ich tekstów, szuka meandrów ludzkiej kondycji. Kieruje zatem swe zainteresowania na zawarte w tych dziełach egzystencjalne motywy, które je odsłaniają 29 .

Ja chciałbym jednak pozostać przy nazwie historii życia, bo - jak sądzę - lepiej oddaje ona cele badawcze, metody i źródła, którymi należy się posłużyć, aby przedstawić dzieje ludzkiego życia; bliżej jej do terminu life history. Poza tym lepiej jest osadzona w tradycji historiograficznej i tradycji innych nauk.

\section{LIFE HISTORY - DWOJAKIE ŹRÓDŁO INSPIRACJI POZNAWCZYCH}

Są dwa poziomy, na których widoczna jest inspiracja life history. Poziom pierwszy to historia życia widziana w kontekście nauk przyrodniczych. Poziom drugi to historia życia ujęta w kontekście narracji biegu życia człowieka, typowa dla współczesnych nauk społecznych i teorii literatury. Jednym słowem dla badań jakościowych.

W tym pierwszym podejściu mówimy o dziedzinie wiedzy doskonale rozwiniętej i mocno osadzonej w kontekście teorii ewolucji. Tak piszą o tym dwaj wybitni antropolodzy Kim Hill i Hillard Kaplan:

Teoria historii życia (Life History) w biologii skupia badania procesów ewolucyjnych kształtujących porządek wydarzeń życia, ze szczególnym uwzględnieniem wieku płodności i śmiertelności [...]. Kluczowe dla teorii historii życia jest założenie, że selekcja naturalna w kalendarzu wydarzeń życia, takich jak wzrastanie, dojrzewanie, reprodukcja i śmierć, zasadza się na ekologii produkcji energii i przypadkowości zgonówº ${ }^{30}$.

Tak pojęta teoria historii życia ma swoją odległą przeszłość sięgającą jeszcze samych teorii Karola Darwina i Alfreda Russela Wallace'a. Po okresie gruntownego unaukowienia w latach 30. ubiegłego stulecia i pojawieniu się teorii opartych o matematyczne modele strategii życia w latach 50. dynamicznie rozwijała się w ostatnim dziesięcioleciu ubiegłego wieku ${ }^{31}$. Ten czas przyniósł też ożywienie w wykorzystywaniu podejścia właściwego life history theory do badań w zakresie historii

29 E. Domańs ka, Historia egzystencjalna, Warszawa 2012, s. 12.

30 "Life history theory in biology organizes research into the evolutionary forces shaping the timing of life events, with a particular focus on age-schedules of fertility and mortality [...] Fundamental to life history theory is the recognition that natural selection on the timing of life events, such as growth, maturation, reproduction, and death, depends on the ecology of energy production and mortality hazard, K. Hill, H. Ka pla n, Life History Traits in Humans: Theory and Empirical Study, „American Review of Anthropology"1999, no. 28, s. 398.

31 The Evolution of Life Histories: Theory and Analysis, ed. D.A. Ro ff, New York 1992; J. Baker, rev. of D.A. Roff, The Evolution of Life Histories: Theory and Analysis, „Ecology” 1994, vol. 75, no. 1, s. $266-267$. 
społecznej, bazującej na paradygmacie historii jako nauki społecznej. Pojawiły się bardzo kuszące perspektywy również i w rozwijającym się poglądzie o konieczności szukania więzów zespalających nauki przyrodnicze oraz społeczne na gruncie tak zwanej biohistorii. Kluczowym pojęciem dla tego nurtu badań stało się pojęcie „biegu życia" (life course). Zaczęto coraz częściej mówić o paradygmacie life course czy wręcz o perspektywie life course $e^{32}$. W tym miejscu trzeba zaznaczyć, że perspektywa taka znalazła w historii społecznej swoją solidną bazę w badaniach demografii historycznej, dodajmy: w wieloletniej perspektywie tych badań, szczególnie ich gałęzi opartej o metodę nominatywną Henriego oraz w całej gamie prac powstałych na bazie jej wykorzystania w różnych ośrodkach i punktach kuli ziemskiej. Nie chodzi tu bynajmniej o stwierdzenie, że demografia historyczna jest swoistym przedłużeniem life history lub że ta koncepcja nauk przyrodniczych leżała u podstaw jej rozwoju. Po prostu w pewnym momencie jej rozwoju, po wszystkich możliwych próbach wyjaśnienia szeregu zjawisk, jak na przykład pojęcia płodności naturalnej Henriego czy przyczyn transformacji demograficznej, kategoria porządku życia i analiza oparta o porządek życia wydawały się nieść z sobą znaczący potencjał organizujący narracji. Było to też o tyle uzasadnione, że owo pojęcie, stosowane w naukach przyrodniczych od początku lat 60., przeniknęło do analiz demograficznych, dając nadzieję na nowe otwarcie paradygmatu historii jako nauki społecznej, otworzyło ją bowiem w kierunku biohistorii.

$\mathrm{Z}$ pojęciem life course wiążą się nieporozumienia terminologiczne ${ }^{33}$. Duane $\mathrm{F}$. Alwin na przykład zwraca uwagę na niejednoznaczność zasadniczego konceptu life course. Uważa, że niesłuszne jest niedostrzeganie różnic i częste wymienne stosowanie terminów life course i life cycle. Pojęcia te ogólnie chce widzieć wśród od dawna używanych w naukach przyrodniczych określeń związanych z biologiczną analizą życia, takich jak life expectance (nadzieja dalszego trwania życia), life span (trwanie życia), life space (przestrzeń życia), life trajectory (trajektoria życia), lifetime (czas życia), life pathway (ścieżka życia), lifeworld (świat życia) czy lifestyles (style życia). Termin life course traktuje jako relatywnie nowy w porównaniu na przykład z „nadzieją dalszego trwania życia” czy „trwaniem życia”. Zwraca jednak uwagę, że wszystkie one dotyczą nieco odmiennych aspektów życia człowieka ${ }^{34}$. Alwin po dogłębnym przeanalizowaniu stosowania tych pojęć pisze, że w okresie swego funkcjonowania w nauce life course przyjęło pięć zasadniczych odniesień semantycznych: (a) jako czas lub wiek, (b) historia życia jako etapy życia, (c) bieg życia jako przypadki życia, przejścia i trajektorie, (d) bieg życia jako trwanie życia,

32 Wśród prac kształtujących debatę na ten temat wartości tego rodzaju ujęć warto wspomnieć m.in.: A.M. O'R and, M.L. Krecker, Concepts of the life cycle: Their history, meanings, and uses in the social sciences [w:] eds. W.R. Scott, J.R. Blake, „Annual Review of Sociology” 1991, vol. 16, s. 241-262; G.H. Eld er Jr., M.K. John son, R. Crosnoe, The emergence and development of life course theory [w:] Handbook of the life course, eds. J.T. Mortimer, M.J. Sh a na han, New York 2003, s. 3-19.

${ }_{33}$ G.H. Elder Jr., The life course [w:] Encyclopaedia of sociology, 2nd ed., vol. 3, New York 2000, s. $1614-1622$.

${ }^{34}$ D.F. Alw in, Integrating Varieties of Life Course Concepts, ,,The Journal of Gerontology. Series B: Psychological Sciences and Social Sciences” 2012, no. 67, s. 207. 
(e) bieg życia jako wynik życiowych wpływów (kumulacja) okresów wcześniejszych na życie dojrzałe ${ }^{35}$.

Nieco inaczej do zagadnienia podchodzą socjolodzy przywiązujący większą wagę do semantyki słowa life cycle. Podobnie jak w badaniach znaczeń Alwina zdają oni sobie sprawę z różnic pojęć i faktu, że każde z wymienionych wyżej słów kluczowych posiada inne odniesienia praktyczne. Słusznie konkludują, że jeśli ktokolwiek ma nadzieję na postępującą konkretyzację języka nauk społecznych w oparciu o bazę doświadczeń nauk przyrodniczych, to w przypadku life history musi ją uznać za złudną ${ }^{36}$.

Drugi poziom inspiracji, niejako jej drugą stronę, widzimy w badaniach jakościowych. Mam tu na myśli szczególnie zjawisko doskonale uchwycone przez Kaję Kaźmierską w odniesieniu do socjologii szukającej przyczyn powodzenia metody biograficznej:

W epoce ponowoczesności, proponującej indywidualizm, kreatywność, przedsiębiorczość, niezależność, innowacyjność zauważyć można zmianę charakteru dyskursu socjologicznego, który już „nie analizuje rzeczywistości, lecz ją obsługuje”. Stąd popularność metody biograficznej, która zwłaszcza jeśli uprawiana jest powierzchownie i banalnie, doskonale wspiera opisany stan rzeczy poprzez pokazywanie indywidualnego, sprawczego i autonomicznego wymiaru działań jednostki [podkreśl. - K.Z.]

Obecna sytuacja w istocie jednak i podobnie do tego, co obserwowaliśmy w przypadku inspiracji nauk przyrodniczych, promuje od dawna istniejące badania w zakresie historii życia. Już Florian Znaniecki i William Thomas w Chłopie polskim $w$ Ameryce pokazali, jak wielkim oraz ważnym narzędziem w analizie zjawisk społecznych jest historia życia, jak istotne dla poznania społecznych mechanizmów zachowań stają się studia indywidualnych doświadczeń ludzi. Metoda autobiograficzna, zaproponowana przez Floriana Znanieckiego, znalazła w polskiej socjologii miejsce szczególne. Była rozwijana przez jego uczniów: Jana Szczepańskiego i Józefa Chałasińskiego, a następnie kontynuowana przez kolejnych badaczy związanych z Towarzystwem Pamiętnikarstwa Polskiego, m.in. Bronisława Gołębiowskiego i Franciszka Jakubczaka. Postrzegali oni relacje pamiętnikarskie jako zapis zmian społeczno-kulturowych, jakie stały się udziałem Polaków w XX wieku, służące rozpoznaniu aktualnych problemów społecznych. Rezultaty ich prac oraz refleksji metodologicznej nad szczególnym typem materiału badawczego publikowane były w dużej mierze na łamach „Pamiętnikarstwa Polskiego”, organu TPP. Podobny sposób podejścia do analizy pamiętników reprezentują prace innego ośrodka badań nad dokumentami osobistymi - Instytutu Gospodarstwa Społecznego Szkoły Głównej Handlowej, utworzonego przez Ludwika Krzywickiego. Te tradycje ciągle oczekują

${ }^{35}$ „(a) Life course as time or age, (b) life course as life stages, (c) life course as events, transitions, and trajectories, (d) life course as life-span human development, and (e) life course as early life influences (and their cumulation) on later adult outcomes", D.F. Alwin, op. cit., s. 206, 213.

${ }^{36}$ A.M. O'Rand, M.L. Krecker, op. cit., s. 259.

${ }^{37}$ K. Kaźmierska, Wstęp [w:] Metoda biograficzna w socjologii, red. K. Kaźmierska, Kraków 2012, s. 10. 
na pełniejszą i bardziej znaczącą realizację w masowym wykorzystaniu potężnych zasobów pamiętników polskich z XX wieku. Osiągnięcia socjologicznej szkoły chicagowskiej, której fundamentem są badania Thomasa i Znanieckiego, w powszechnym odczuciu nie utraciły na swym znaczeniu w ujęciach typowych dla historii życia, jakkolwiek w dwudziestowiecznym rozwoju socjologii pojawiały się koncepty nowe, w tym zakresie powstałe na gruncie socjologii interpretatywnej ${ }^{38}$. Szczególną uwagę zwracają tu osiągnięcia niemieckiej szkoły socjologicznej, zwłaszcza Fritza Schützego, i jego koncepcje zgłaszane w zakresie socjologii biografistycznej, które na gruncie historii zyskały szczególne uznanie w historii mówionej ${ }^{39}$.

Nie jest moim zamiarem wykazywanie w tym miejscu, jak bardzo pożyteczne dla rozwoju historii jako nauki stały się narodziny i rozwój tej gałęzi badań historycznych, jakim jest historia mówiona; jak bardzo podkreśliła ona znaczenie istoty narracji jako przedmiotu analizy historycznej; jak dalece rozwija to nasze możliwości wejścia na poziom zbliżający nas do psychologii i wiedzę $\mathrm{z}$ tej materii zaczyna czynić coraz bardziej istotną. $Z$ psychologicznego punktu widzenia narracja jest zawsze najistotniejszym sposobem wyrażenia indywidualnego doświadczenia. Za pionierskie w polskiej historiografii historii mówionej uznaję wspomniane wyżej rozważania Marty Kurkowskiej-Budzan nad pozycją narratora. Dodam tylko, że - na co zwracają uwagę psycholodzy - na narrację należy patrzyć zawsze jako na „personal experience as expressed in or communicated in language" (doświadczenie osobiste jako wyrażone i/lub zakomunikowane $\mathrm{w}$ języku) ${ }^{40}$. W tym sensie, niezależnie od formy tego wyrażenia, nie ma historii bez narracji.

Nie tu miejsce, aby rozwijać trywialną myśl, iż badania jakościowe zyskują w naukach społecznych szczególne znaczenie po rewolucji postmodernistycznej. Stanowią swoistą reakcję na formalizację ujęć modernistycznych, ale też są głęboką odpowiedzią na uproszczenia, jakie niosła z sobą analiza strukturalna. Wpisują się doskonale w zwrot kulturowy i podążają w kierunku, który wydaje się prowadzić do wyjścia z - wydawałoby się - zamkniętego kręgu sprzeczności faktów kultury i faktów natury. Ta sprzeczność zaś w perspektywie historii życia stanowi punkt wyjścia naszych obecnych rozważań. Czas zatem na konkluzję.

38 Zob. m.in. A. Rokuszewska-Pawełek, Miejsce biografii w socjologii interpretatywnej. Program socjologii biografistycznej Fritza Schützego, „ASK” 1996, nr 1, s. 37-54; K. Kaźmierska, Metoda biogragiczna..., s. 107; K. Kaźmi ers ka, Badania biograficzne w naukach społecznych, „Przegląd Socjologii Jakościowej” 2013, T. IX, nr 4, s. 6-10.

${ }^{39}$ M. Kurkowska-Budzan, Informator, świadek historii, narrator. Kilka watków epistemologicznych i etycznych Oral History, „Wrocławski Rocznik Historii Mówionej” 2011, nr 1, s. 9-34.

${ }^{40}$ Identity and Story. Creating Self in Narrative, eds. D.P. Mc Ada m s, R. J o s s els o n, A. Lieblich, Baltimore, MD 2002, s. 4. 


\section{KONKLUZJA: O WARTOŚCI POZNAWCZEJ HISTORII ŻYCIA SŁÓW KILKA}

Trudno całościowo w tym krótkim, przeglądowym i z konieczności powierzchownym tekście wskazać wszystkie konsekwencje przyjęcia perspektywy historii życia jako punktu spojrzenia na problemy badawcze historii. Perspektywa ta jest obecna i może pojawić się w każdej gałęzi wiedzy historycznej; od historii politycznej, przez historię społeczną, gospodarczą, historię kultury, historię Holokaustu, historię mówioną, aż po demografię historyczną. Niewątpliwie dowartościowuje ona znaczenie egodokumentów jako źródeł. Ważne jednak, aby zauważyć, że nie może ograniczać się wyłącznie do nich. Wręcz przeciwnie - jedną z podstawowych zalet tej perspektywy stanowi to, że daje ona możliwość zróżnicowanej analizy źródeł aktowych, masowych informacji różnej proweniencji. Dowodzi złożoności procesów społecznych i jest w stanie ukazać ich skomplikowany charakter, często obalając mity teoretyczne oraz mityczną wizję historii narodowej. To podejście czyni bowiem ważnym każde wyrażone i zachowane w źródle ludzkie doświadczenie.

Szczególną nadzieję budzi we mnie odniesienie zauważonych czasami nieźle zbadanych strukturalnie społecznych procesów do poziomu takiego właśnie doświadczenia. O co chodzi? Posłużę się przykładem z niedawno przeprowadzonych badań, w których bieg życia i perspektywa życia odegrały fundamentalną rolę. Historia Rzeczypospolitej Obojga Narodów była i jest źródłem wiedzy mitycznej powielanej nie tyle może w naukowych badaniach, choć i tu zdarzają się takie przypadki, ile w społecznym odbiorze widocznym w kulturze czy w analizach niezbyt mocno osadzonych $\mathrm{w}$ materii historii. Jednym $\mathrm{z}$ takich głęboko zakorzenionych i nadal powielanych przekonań jest mit ,niewolnictwa” chłopów w epoce gospodarki dworskiej. Chłopi w Rzeczypospolitej szlacheckiej mieli być grupą całkowicie podporządkowaną szlachcie, niezmienną w swej strukturze wewnętrznej, nieruszającą się z miejsc swego zamieszkania. Mieli być niewolnikami na kształt niewolników $\mathrm{w}$ Stanach Zjednoczonych $\mathrm{w}$ dobie przed wojną secesyjną. Ta teza nabiera ostatnio coraz większego znaczenia, zyskując rangę współczesnego mitu historycznego w postaci tak zwanej „ludowej historii Polski”. Konceptu może i użytecznego z punktu widzenia współczesności w punkcie, w którym uzmysławia wielu ludziom w Polsce chłopskie korzenie ich kultury, ale upraszczającego czy wręcz prostackiego w odniesieniu do doświadczeń człowieka żyjącego w epoce gospodarki dworskiej. Ukazała się niedawno książka, której autor, Mateusz Wyżga, poddał ten mit gruntownej weryfikacji na podstawie badań opartych o ogrom źródel ${ }^{41}$. Perspektywa historii życia nie jest mu obca, wykorzystuje więc spisy ludności, źródła podatkowe, księgi sądowe wiejskie, spisy celne, księgi miejskie, inwentarze dóbr ziemskich. Tym, co je łączy, jest próba spojrzenia na dane z perspektywy doświadczeń indywidulanych, konkretnych chłopów i mieszczan, mieszkańców dóbr szlacheckich i kościelnych w regionie

${ }^{41} \mathrm{M}$. Wyżga, Homo movens. Mobilność chtopów w mikroregionie krakowskim w XVI-XVIII wieku, Kraków 2019. 
krakowskim w okresie XVI-XVIII wieku. Osób znanych mu z imienia i nazwiska. W konkluzji młody krakowski badacz stwierdził, że badania te przedstawiły mu

obraz wysoce mobilnego społeczeństwa Rzeczypospolitej przedrozbiorowej, gdzie wskaźniki migracji, pomimo panowania systemu folwarczno-pańszczyźnianego (ograniczającego przynajmniej w sposób formalny wychodźstwo ludności poddańczej, tj. chłopów), okazały się zbliżone do innych państw ówczesnej Europy. Zbliżone były zasięgi pokonywanych przemieszczeń, jak również wysoki poziom małżeństw egzogamicznych (tj. z osobą spoza społeczności lokalnej). [...] Udało mi się równocześnie ustalić wbrew dotychczasowym twierdzeniom, że pańszczyzna zupełnie nie blokowała przepływów ludnościowych w obrębie struktury społecznej wsi, jak i między miastem a wsią. To opieka patrymonialna roztaczana przez dwór nad podległą ludnością chłopską mogła lepiej wpłynąć na decyzję o pozostaniu na wsi niż ciemiężenie poddanych $^{42}$.

Taki obraz przeszłości ma się nijak do lansowanej dzisiaj przez zwolenników ludowej historii Polski idei „niewolnictwa” w czasach gospodarki pańszczyźnianej. Próba sztucznego przeniesienia kategorii historii Stanów Zjednoczonych Ameryki Północnej jest bowiem zasadniczym pomyleniem porównywalnych w czasie i przestrzeni kategorii zjawisk.

Od kilku lat staram się realizować praktycznie założenia wskazanej tu perspektywy. Dzięki współpracy z krakowskim wydawnictwem naukowym „Universitas” udało mi się powołać do życia serię wydawniczą „Historia życia”. Zdaję sobie sprawę z faktu, że nie jest to działanie pionierskie w skali wydarzeń historiograficznych końca ubiegłego stulecia. Jednocześnie nie jest moją intencją naśladowanie osiągnięć wspomnianej powyżej serii mikrohistorycznej Giovanniego Leviego i Carla Ginzburga, nie wykluczam natomiast inspirowania się nią, nie zakładam bowiem mikrohistorii jako wyłącznego i jedynego podejścia realizującego perspektywę historii życia. Bardziej interesuje mnie poszukiwanie bogactwa oraz różnorodności form wykorzystywania perspektywy historii życia w badaniach i narracji historycznej. Do dnia dzisiejszego ukazały się w jej ramach trzy monografie pisane przez moich uczniów i współpracowników ${ }^{43}$. Każda z nich podejmuje inny aspekt przeszłości w ujęciu konkretnych ludzkich doświadczeń odpowiadających stwierdzonym tendencjom, istotnym w sieci powiązań zdarzeń i losów ludzi danej epoki. Mówiąc o bogactwie form ujęć historii życia, mam na myśli doświadczenia wynikające z przeprowadzonej przez Bartosza Ogórka analizy biometrycznej znanych z imienia i nazwiska noworodków urodzonych w klinice Uniwersytetu Jagiellońskiego w okresie Wielkiej Wojny, poziomu wyżywienia ludności Krakowa szacowanej według współczesnych miar, jak i opisów jego składników zawartych w egodokumentach z czasów I wojny światowej. Widzimy konkretne doświadczenia ludzi zmuszonych do opuszczenia

42 Ibidem, s. 405.

43 B. Ogórek, Niezatarte piętno? Wpływ I wojny światowej na ludność miasta Krakowa, Kraków 2018; A. B arzy cka-Paździor, Ojcostwo drugiej połowy XIX i na początku XX wieku. Szkice z dziejów rodziny galicyjskiej, Kraków 2019; P. Miodunka, Społeczność małych miast południowej Małopolski od końca XVI do końca XVIII wieku, Kraków 2020. W przygotowaniu są kolejne tomy, czwarty autorstwa Marcina Stasiaka o epidemii polio w Polsce, i piąty: moje studium mikrohistoryczne doświadczeń pewnego proboszcza parafii w Tenczynku w początkach XVIII stulecia. 
miasta Krakowa na skutek zarządzeń władz wojskowych i w związku z tym próbujemy odkryć długotrwałe skutki wojny w życiu krakowian po jej zakończeniu. Patrzymy na przykłady zachowań rodzinnych ojców zanotowane w pamiętnikach i korespondencji krakowian odniesione do warunków prawnych i oczekiwań społecznych epoki w analizie Agaty Barzyckiej-Paździor. Patrzymy na losy mieszczan w małych osadach miejskich w Małopolsce czasów nowożytnych, na życie rodzinne, gospodarkę i cykl życia tych ludzi w ujęciu Piotra Miodunki. Tym, co nierozłącznie splata te odmienne studia, pozostaje los konkretnych, znanych z imienia i nazwiska ludzi widziany w perspektywie społecznego otoczenia ich życia.

Jakby na przekór przekonaniom Fiodora Dostojewskiego, wszystkie te prace pokazują, że

Są ludzie, o których trudno jest powiedzieć coś takiego, co by od razu i całkowicie wyraziło ich najbardziej typowe i charakterystyczne cechy; to są ci ludzie, których zazwyczaj nazywa się „Zwykłymi”, „większością” i którzy rzeczywiście stanową większość każdego społeczeństwa,

ale też dowodzą, że aby opowiedzieć o ich życiu, historyk w odróżnieniu od literata niekoniecznie musi

przeważnie brać pewne typy społeczne i przedstawiać je obrazowo i artystycznie - typy nader rzadko spotykane w życiu jako pewne całości, a które jednak są bardziej rzeczywiste niż sama rzeczywistość.

\section{BIBLIOGRAFIA}

Abbott A., Life Cycles in Social Science History, „Social Science History” 1999, vol. 23, no. 4, Special Issue: What Is Social Science History?, s. 481-489.

Alvin D.F., Integrating Varieties in Life Course Concepts, „The Journals of Geronotology Series B: Psychologicals Sciences and Social Sciences” 2012, no. 67, s. 206-220.

Barker G., Desjardins E., Pearce T., Entangled Life: Organism and Environment in the Biological and Social Sciences, Series „History, Philosophy and Theory of the Life Sciences", vol. 4, New York-London 2014.

Baker J., rev. of D.A. Roff, The Evolution of Life Histories: Theory and Analysis, „Ecology" 1994 , vol. 75 , no. 1, s. 266-267.

Barzycka-Paździor A., Ojcostwo drugiej połowy XIX $i$ na początku XX wieku. Szkice $z$ dziejów rodziny galicyjskiej, t. 2, Kraków 2019.

Casement W., Husserl and the Philosophy of History, „Theory and History” 1988, vol. 27, no. 3, s. 229-240.

Chakravarty U., Rewriting History: The Life and Times of Pandita Ramabai, 2005.

Chang K., rev. of, S. Normandin, C.T. Wolfe, Vitalism and the Scientific Image in PostEnlightenment Life Science, 1800-2010 (History, Philosophy and Theory of Life Sciences, vol. 2), „Early Science and Medicine” 2014, vol. 19, no. 4, s. 376-378.

Chase-Harrell P., rev of W.J. Murtagh, Keeping Time: The History and Theory of Preservation in America; Robert Blair St. George ed., Material Life in America, 1600-1860, „The New England Quarterly” 1989, vol. 62, no. 3, s. 468-473. 
Coulson T., Tuljapurkar S., Childs D.Z., Using Evolutionary Demography to Link Life History Theory, Quantitative Genetics and Population Ecology, ,Journal of Animal Ecology" 2010, vol. 79, no. 6, s. 1226-1240.

Crain C., A Critic at Large: Surveillance Society: The Mass Observation Movement and the Meaning of Everyday Life, „The New Yorker”, September 11, 2006, s. 76-82.

Dilthey W., O istocie filozofii i inne pisma, Warszawa 1987.

Domań ska E., Historia egzystencjalna, Warszawa 2012.

Domańska E., Mikrohistorie, Poznań 2005.

Elder G.H. Jr., Johns on M.K., Crosnoe R., The emergence and development of life course theory [w:] Handbook of the life course, eds. J.T. Mortimer, M.J. Shanahan, New York 2003.

Ginzburg C., Ponti C., The Name and the Game. Unequal Exchange and Historiographic Marketplace, Microhistory and the Lost People of Europe, eds. E. Muir, G. Ruggiero, Baltimore 1991.

Ginzburg C., Tedeschi J., Tedeschi A.C., Microhistory: Two or Three Things That I Know About It, „Critical Inquiry” 1993, vol. 20, no. 1, s. 10-35.

Goody J., Poskromienie myśli nieoswojonej, Warszawa 2011.

Górzan K., Giovanniego Levy'ego koncepcja mikrohistorii, „Historyka” 2007-2008, T. XXXVII-XXXVIII, s. 77-90.

Hill K., Kaplan H., Life History Traits in Humans; Theory and Empirical Study, „American Review of Anthropology" 1999, vol. 28, s. 397-430.

Identity and Story. Creating Self in Narrative, eds. D.P. Mc Adams, R. Josselson, A. Lieblich, Baltimore, MD 2002.

Jenner G., Milion lat w jeden dzień. Fascynująca historia życia codziennego od Jaskini do globalnej wioski, thum. J. Mastalerz, Warszawa 2016.

Kaczmarek K.M., Mechanizmy ewolucji religii, Poznań 2013.

Kaźmierska K., Badania biograficzne w naukach społecznych, „Przegląd Socjologii Jakościowej” 2013, t. IX, nr 4, 6-10.

Kelley D.R., Granice historii. Badanie przeszłości w XX wieku, Warszawa 2009.

Kołakowski A., Życie-kultura-cywilizacja. Historiozofia Oswalda Spenglera jako wyraz kryzysu i krytyki kultury, „Archiwum historii filozofii i myśli społecznej” 1976, T. 22, s. $103-139$.

Kuczyński J., Filozofia życia, Warszawa 1965.

Kula W., Problemy i metody historii gospodarczej, Warszawa 1983.

Kurkowska-Budzan M., Informator, świadek historii, narrator. Kilka wątków epistemologicznych i etycznych Oral History, „Wrocławski Rocznik Historii Mówionej” 2011, nr 1, s. 9-34.

Kushner T., We Europeans? Mass-Observation, 'Race' and British Identity in the Twentieth Century, „Studies in European Cultural Transition” 2004, no. 25.

Luckinbill L.S., An Experimental Analysis of a Life History Theory, „Ecology” 1984, vol. 65 , no. 4 , s. $1170-1184$.

Material Life in America, 1600-1860, ed. R.B. St. George, Northeastern 1981.

McAlster A.L., Historia życia, Warszawa 1979.

McKinley Runyan W., Life Histories and Psychobiography: Explorations in Theory and Method, Oxford 1984.

Metoda biograficzna w socjologii. Antologia tekstów, red. K. Kaźmierska, Kraków 2012.

Méthot P.-O., rev. of, S. Normandin, C.T. Wolfe, Vitalism and the Scientific Image in Post-Enlightenment Life Science, 1800-2010. History, Philosophy \& Theory of the Life Sciences, Volume 2, „Journal of the History of Biology” 2014, vol. 47, no. 3, s. 497-499. Miodunka P., Społeczność matych miast poludniowej Małopolski od końca XVI do końca 
XVIII wieku, Kraków 2020.

Murtagh W.J., The History and Theory of Preservation in America, Hoboken, New Jersey 2010.

Nicoglou A., rev. of, G. Barker, E. Desjardins, T. Pearce, Entangled life: organism and environment in the biological and social sciences. Series: History, philosophy and theory of the life sciences, vol. 4, „History and Philosophy of the Life Sciences” 2015, vol. 37, no. 2, s. 222-224.

Nipperday T., Rozważania o niemieckiej historii. Eseje, thum. A. Kopacki, Warszawa 1999.

Ogórek B., Niezatarte piętno? Wptyw $i$ wojny światowej na ludność miasta Krakowa, Kraków 2018.

O'Rand A.M., Krecker M.L., Concepts of the life cycle: Their history, meanings, and uses in the social sciences [w:] eds. W.R. Scott, J.R. Blake, „Annual Review of Sociology” 1991, vol. 16, s. 241-262.

Paczkowska-Łagowska E., Logos życia. Filozofia hermenutyczna w kręgu Wilhelma Diltheya, Gdańsk 2000.

Pomeranz K., Social History and World History: From Daily Life to Patterns of Change, „Journal of World History” 2007, vol. 18, no. 1, s. 69-98.

Pomper P., The Structure of Mind in History: Five Major Figures in Psychohistory, New York 1985.

Przyłębski A., Hermeneutyczna antropologia Wilhelma Diltheya, „Analiza i Egzystencja” 2010, nr 19, s. 55-70.

Rokuszewska-Pawełek A., Miejsce biografii w socjologii interpretatywnej. Program socjologii biografistycznej Fritza Schützego, „ASK” 1996, no. 1, s. 37-54.

Roos A.M., rev. of P. Distelzweig, B. Goldberg, E. Ragland, Early Modern Medicine and Natural Philosophy, History, Philosophy, and Theory the Life Sciences 14, „Early Science and Medicine" 2016, vol. 21, no. 4, s. 410-412.

Rosenwald G.C. Task, Process, and Discomfort in the Interpretation of Life Histories [w:] Up close and Personal. The Teaching and Learning of Narrative Research, eds. R. Josselson, A. Lieblich, D.P. McAdams, Washington DC 2003.

Schnädelbach H., Filozofia w Niemczech 1831-1933, thum. K. Krzemieniowa, Warszawa 1992.

Soroko E., Poziom autonarracyjności wypowiedzi i użyteczność wybranych sposobów ich generowania, UAM, Poznań 2007 [praca doktorska w Instytucie psychologii UAM, promotor W.J. Paluchowski].

The Evolution of Life Histories: Theory and Analysis, ed. D.A. Roff, New York 1992.

Vijay D., Life history: a tool for a humanistic understanding of history author(s), „Proceedings of the Indian History Congress" 1991, vol. 52, s. 950-956.

Wurgaft L.D. rev. of W. McKinley Runyan, Life Histories and Psychobiography: Explorations in Theory and Method; P. Pomper, The Structure of Mind in History, Five Major Figures in Psychohistory, „The Journal of Modern History” 1987, vol. 59, no. 2, s. 356-358.

Wyżga M., Homo movens. Mobilność chłopów w mikroregionie krakowskim w XVI-XVIII wieku, Kraków 2019.

Zamorski K., Historia życia u źródet. Włoskie korzenie [w:] Badacze przeszłości wobec wyzwań XIX-XXI wieku, red. K. Błachowska, Z. Romek, M. Wolniewicz, Warszawa 2013.

Zamorski K., Czym jest historia serii Pierre Chaunu?, „Zeszyty Naukowe UJ. Prace Historyczne" 1980, z. 66. 